\title{
Alkynyl-Containing Peptides of Marine Origin: A Review
}

\author{
Qiu-Ye Chai ${ }^{1,2,+}$, Zhen Yang ${ }^{3,+}$, Hou-Wen Lin ${ }^{1, *}$ and Bing-Nan Han ${ }^{1, *}$ \\ 1 Research Center for Marine Drugs, Department of Pharmacy, State Key Laboratory of Oncogenes and \\ Related Genes, Renji Hospital, School of Medicine, Shanghai Jiao Tong University, Shanghai 200127, China; \\ chaiqiuye123@sina.cn \\ 2 School of Pharmacy, Jiangxi University of Traditional Chinese Medicine, Nanchang 330000, China \\ 3 Department of Pharmacy, Graduate School, Hunan University of Chinese Medicine, \\ Changsha 410208, China; zyyangzhen1991@163.com \\ * Correspondence: franklin67@126.com (H.-W.L.); hanbingnan@shsmu.edu.cn (B.-N.H.); \\ Tel.: +86-21-6838-3346 (B.-N.H.); Fax: +86-21-5873-2594 (B.-N.H.) \\ + These authors contributed equally to this work.
}

Academic Editor: Se-Kwon Kim

Received: 19 September 2016; Accepted: 16 November 2016; Published: 23 November 2016

\begin{abstract}
Since the 1990s, a number of terminal alkynyl residue-containing cyclic/acyclic peptides have been identified from marine organisms, especially cyanobacteria and marine mollusks. This review has presented 66 peptides, which covers over $90 \%$ marine peptides with terminal alkynyl fatty acyl units. In fact, more than $90 \%$ of these peptides described in the literature are of cyanobacterial origin. Interestingly, all the linear peptides featured with terminal alkyne were solely discovered from marine cyanobacteria. The objective of this article is to provide an overview on the types, structural characterization of these unusual terminal alkynyl fatty acyl units, as well as the sources and biological functions of their composed peptides. Many of these peptides have a variety of biological activities, including antitumor, antibacterial, antimalarial, etc. Further, we have also discussed the evident biosynthetic origin responsible for formation of terminal alkynes of natural PKS (polyketide synthase)/NRPS (nonribosome peptide synthetase) hybrids.
\end{abstract}

Keywords: marine cyanobacteria; mollusk; alkynyl peptides; biological activity; absolute configuration

\section{Introduction}

As oceans comprise over $70 \%$ of the earth's surface and harbor a tremendous variety of flora and fauna, marine habitat represents a rich source of diverse chemical structures and biological activities of natural products [1], which include alkaloids, terpenoids, peptides, polyketides, steroids, etc. Peptides as an important bioactive natural product, present in many marine species, including sponges, ascidians, seaweeds, mollusks, and marine microorganisms, have been extensively studied $[2,3]$. Interestingly, diverse structural classes of peptides such as linear peptides, linear depsipeptides, linear lipopeptides, cyclic peptides, cyclic depsipeptides, and cyclic lipopeptides have been discovered from all of these marine species. The broad bioactivity spectrum of marine peptides has high medicinal potential which attracts the attention of the pharmaceutical industry. Since the discovery of the first marine-derived antitumorcyclic peptide, ulithiacyclamide, many marine anticancerpeptides have entered into clinical trials with good prospects for drug development [4-6], such as kahalalide F, hemiasterlin, dolastatins, cemadotin, soblidotin, didemnins, aplidine, etc. [7]. Cyclic peptides as a valuable lead for drug discovery with better resistance to enzymatic degradation and higher bioavailability in vivo have attracted considerable attention for further study in the areas of marine natural products $[4,8]$. Acyclic peptides with the prospect of pharmacological activity are also 
promising, such as the well-known anticancer lead dolastatin 10 isolated from both sea hare Dollabella auricularia [9] and its diet of marine cyanobacterium, the Symploca species [10], whose synthetic derivatives have been used in clinical phase III trials [7]. In recent years, a number of structurally intriguing peptides containing diverse fatty acyl units with a terminal alkyne functional group have been found in multiple marine organisms [11-14], especially marine cyanobacteria and mollusks. The structural characteristics of these peptides with various unusual amino acid residues have displayed their variety of biological functions as antitumor, antibacterial, antimalarial activities, etc., which seemed in some cases correlated to the presence of the terminal alkynyl moieties [14-16]. Cyanobacteria, also known as blue-green algae, are ancient photosynthetic prokaryotes living in a wide range of habitats including open oceans, tropical reefs, shallow water environments, and terrestrial substrates. The rich elaboration of biologically active natural products has assisted some of these organisms to survive in predator-rich ecosystems. A major part of cyanobacterial secondary metabolites arepeptides or possess peptidic substructures, which contribute to the more than 600 cyanobacterial peptides discovered thus far $[17,18]$. Mollusks are the largest marine phylum, comprising about $23 \%$ of all the named marine organisms. The gastropods (snails and slugs) are by far the most numerous mollusks in terms of classified species, and account for $80 \%$ of the total [19]. To date, over 100 mollusks peptides with diverse structures have been reported (Data based on reviewing the literatures, Marine Natrual Products in Natural Product Reports published during 1985-2015), some of which displayed a variety of bioactivities as antitumor, anti-HIV, ion blockers, etc. [20,21].

In this review, we have provided an overview of the types and structural characterization of these unusual terminal alkynyl fatty acyl units, as well as the sources and biological functions of their composed peptides from marine cyanobacteria and mollusks. Further, we have also discussed the evident biosynthetic origins responsible for formation of terminal alkynes of natural PKS (polyketide synthase)/NRPS (nonribosome peptide synthetase) hybrids, providing perspective insight for drug discovery research.

\section{Cyclic Peptides Containing Terminal Alkyne}

A number of terminal alkynylfatty acyl moieties are identified in the cyclic/acyclic marine peptides, which are different by structure and bioactivities (Table 1, Figure 1). Onchidin as the first terminal alkynyl-containing cyclic peptide, featured with 3-amino-2-methyl-7-octynoicacid (Amoya, a) moiety was isolated as a molluscan metabolite in 1994 [11]. Since then, Amoya as a component of cyclic peptides has been identified from many marine cyanobacterial metabolites including ulongapeptin, guineamide $\mathrm{C}$, and companeramides $\mathrm{A}$ and $\mathrm{B}$. It is likely that the 3-hydroxy-2-methyloct-7-ynoic acid (Hmoya, $\mathbf{b}$ ) moiety was originally discovered in onchidin B from a marine mollusk, and subsequently identified in many cyanobacterial metabolites such as antanapeptin A and D, trungapeptin A, and hantupeptin A. Interestingly, abromine-containing 3-hydroxy-2-methyloct-7-ynoic acidmoiety (Br-Hmoya, c) was subsequently identified in several veraguamides isolated from marine cyanobacteria as well. The 2,2-dimethyl-3-hydroxy-7-octynoic acid (Dhoya, d) moiety was first discovered as a fatty acyl component in kulolide-1, from a cephalaspidean mollusk, Philinopsis speciosa, thereafter reported in many cyclic peptides with cyanobacteria origin as yanucamides $\mathrm{A}$ and $\mathrm{B}$, pitipeptolide $\mathrm{A}$, viequeamides $\mathrm{A}$, and more. The 3-amino-6-octyneoic acid (Aoy, e) residue and the 5,7-dihydroxy-2,6-dimethyldodec-2-en-11-ynoic acid (Dddd, f) residue have been only identified in dolastatin 17 from a marine mollusk Dolebella auricularia and in Palau'amide from a marine cyanobacteria Lyngbya sp., respectively. 
Table 1. Terminal alkynyl-containing cyclic/acyclic peptides from marine cycanobacteria and mollusks.

\begin{tabular}{|c|c|c|c|c|}
\hline Moiety Unit & Compound & Organism & Bioactivities & Reference \\
\hline \multirow{9}{*}{ Dhoya } & $\begin{array}{l}\text { Yanucamides A (1) and } \\
\text { B (2) }\end{array}$ & $\begin{array}{c}\text { Marine cyanobacterium } \\
\text { Lyngbya majuscule, } \\
\text { Schizothrix sp. }\end{array}$ & Strong brine shrimp toxicity & [12] \\
\hline & $\begin{array}{c}\text { Pitipeptolides A (3) } \\
\text { Pitipeptolides D-F (4-6) }\end{array}$ & $\begin{array}{l}\text { Marine cyanobacterium } \\
\text { Lyngbya majuscula }\end{array}$ & Antitumor cytotoxicity & {$[22,23]$} \\
\hline & Georgamide (7) & Marine cyanobacterium & anti-HIV cytotoxicity & {$[24]$} \\
\hline & $\begin{array}{c}\text { Mantillamide (10) } \\
\text { Dudawalamide A (11) }\end{array}$ & $\begin{array}{c}\text { Marine cyanobacterium } \\
\text { Lyngbya sp. }\end{array}$ & $\begin{array}{c}\text { Antitumor cytotoxicity } \\
\text { Antimalaria parasites }\end{array}$ & {$[25]$} \\
\hline & Guineamide G (12) & $\begin{array}{c}\text { Marine cyanobacterium } \\
\text { Lyngbya majuscula }\end{array}$ & $\begin{array}{l}\text { Brine shrimp toxicity } \\
\text { Antitumor cytotoxicity }\end{array}$ & [26] \\
\hline & $\begin{array}{c}\text { Cocosamides A-B } \\
(\mathbf{1 3 - 1 4})\end{array}$ & $\begin{array}{c}\text { Marine cyanobacterium } \\
\text { Lyngbya majuscula }\end{array}$ & Antitumor cytotoxicity & [27] \\
\hline & $\begin{array}{c}\text { Viequeamides A-B } \\
(\mathbf{1 5 - 1 6 )} \text { and E-F (17-18) }\end{array}$ & $\begin{array}{c}\text { Marine cyanobacterium } \\
\text { Rivularia sp. }\end{array}$ & Antitumor cytotoxicity & {$[28]$} \\
\hline & Kulolide-1 (38) & $\begin{array}{l}\text { Marine mollusk Philinopsis } \\
\text { speciosa Pease }\end{array}$ & Antitumor cytotoxicity & [29] \\
\hline & Kulokainalide-1 (39) & $\begin{array}{c}\text { Marine cephalaspidean } \\
\text { mollusk Philinopsis speciosa }\end{array}$ & $\begin{array}{l}\text { Moderate antitumor } \\
\text { cytotoxicity }\end{array}$ & {$[30]$} \\
\hline Dhoaa & $\begin{array}{l}\text { Wewakpeptins A and C } \\
\text { (8a-9) }\end{array}$ & $\begin{array}{c}\text { Marine cyanobacterium } \\
\text { Lyngbya semiplena }\end{array}$ & Antitumor cytotoxicity & {$[31]$} \\
\hline \multirow{5}{*}{ Amoya } & Malevamide C (19) & $\begin{array}{c}\text { Marine cyanobacterium } \\
\text { Symplocalaete-viridis }\end{array}$ & No cytotoxicity & {$[32]$} \\
\hline & Guineamide C (20) & $\begin{array}{c}\text { Marine cyanobacterium } \\
\text { Lyngbya majuscula }\end{array}$ & Antitumor cytotoxicity & {$[33]$} \\
\hline & Ulongapeptin (21) & $\begin{array}{c}\text { Marine cyanobacterium } \\
\text { Lyngbya sp. }\end{array}$ & Antitumor cytotoxicity & {$[34]$} \\
\hline & $\begin{array}{l}\text { Companeramides A-B } \\
(\mathbf{2 2 - 2 3 )}\end{array}$ & $\begin{array}{c}\text { Marine cyanobacterium } \\
\text { Leptolyngbya sp. }\end{array}$ & Antiplasmodial activity & [35] \\
\hline & Onchidin (36) & $\begin{array}{c}\text { Marine pulmonate mollusk } \\
\text { Onchidium sp. }\end{array}$ & $\begin{array}{l}\text { Strong antitumor } \\
\text { cytotoxicity }\end{array}$ & {$[11,36]$} \\
\hline \multirow{7}{*}{ Hmoya } & $\begin{array}{l}\text { Antanapeptin A and D } \\
(\mathbf{2 4 - 2 5 )}\end{array}$ & $\begin{array}{l}\text { Marine cyanobacterium } \\
\text { Lyngbya majuscula }\end{array}$ & $\begin{array}{l}\mathrm{Na}^{+} \text {channel modulation } \\
\text { Antimicrobial activity }\end{array}$ & [37] \\
\hline & Trungapeptins A (26) & $\begin{array}{l}\text { Marine cyanobacterium } \\
\text { Lyngbya majuscula }\end{array}$ & $\begin{array}{l}\text { Brine shrimp toxicity and } \\
\text { ichthyotoxicity }\end{array}$ & {$[30,38]$} \\
\hline & Hantupeptin A (27) & $\begin{array}{l}\text { Marine cyanobacterium } \\
\text { Lyngbya majuscula }\end{array}$ & $\begin{array}{l}\text { Brine shrimp toxicity } \\
\text { Antitumor cytotoxicity }\end{array}$ & [39] \\
\hline & $\begin{array}{l}\text { Veraguamides B-F } \\
(\mathbf{2 9 - 3 3 )}\end{array}$ & $\begin{array}{l}\text { Marine cyanobacterium } \\
\text { Symploca cf. hydnoides }\end{array}$ & $\begin{array}{l}\text { Veraguamides A and C, } \\
\text { antitumor cytotoxicity }\end{array}$ & {$[40]$} \\
\hline & Veraguamides H (34) & $\begin{array}{l}\text { Marine cyanobacterium } \\
\text { Oscillatoria margaritifera }\end{array}$ & No cytotoxicity & [13] \\
\hline & Onchidin B (37) & $\begin{array}{c}\text { Marine pulmonate mollusk } \\
\text { Onchidium sp. }\end{array}$ & $\begin{array}{l}\text { Strong antitumor } \\
\text { cytotoxicity }\end{array}$ & {$[11,36]$} \\
\hline & $\begin{array}{l}\text { Kulomo'opunalide-1 (40) } \\
\text { and (41) }\end{array}$ & $\begin{array}{c}\text { Marine cephalaspidean } \\
\text { mollusk Philinopsis speciosa }\end{array}$ & $\begin{array}{l}\text { Moderate antitumor } \\
\text { cytotoxicity }\end{array}$ & [30] \\
\hline Dddd & Palau'amide (35) & $\begin{array}{c}\text { Marine cyanobacterium } \\
\text { Lyngbya sp. }\end{array}$ & $\begin{array}{l}\text { Strong antitumor } \\
\text { cytotoxicity }\end{array}$ & [41] \\
\hline Aoy & Dolastatin 17 (42) & $\begin{array}{c}\text { Marine mollusk Dolebella } \\
\text { auricularia }\end{array}$ & Antitumor cytotoxicity & {$[12,42]$} \\
\hline Oya & $\begin{array}{l}\text { Apramides B and G } \\
(\mathbf{4 4 , 4 7 )}\end{array}$ & $\begin{array}{c}\text { Marine cyanobacterium } \\
\text { Lyngbya majuscula }\end{array}$ & $\begin{array}{c}\text { Apramide A exhibited } \\
\text { stimulating elastase activity }\end{array}$ & [43] \\
\hline \multirow{3}{*}{ Moya } & $\begin{array}{l}\text { Apramides A,D and G } \\
(43,45-46)\end{array}$ & $\begin{array}{c}\text { Marine cyanobacterium } \\
\text { Lyngbya majuscula }\end{array}$ & $\begin{array}{c}\text { Apramide A exhibited } \\
\text { stimulating elastase activity }\end{array}$ & [43] \\
\hline & $\begin{array}{c}\text { Dragonamides A-B } \\
(48-49)\end{array}$ & $\begin{array}{l}\text { Marine cyanobacterium } \\
\text { Lyngbya majuscule Gomont }\end{array}$ & Antileishmaniasis & [44-47] \\
\hline & $\begin{array}{c}\text { Dragonamides C-E } \\
\quad(50-52)\end{array}$ & $\begin{array}{c}\text { Marine cyanobacterium } \\
\text { Lyngbya polychroa }\end{array}$ & Antileishmaniasis & [47] \\
\hline
\end{tabular}


Table 1. Cont.

\begin{tabular}{|c|c|c|c|c|}
\hline Moiety Unit & Compound & Organism & Bioactivities & Reference \\
\hline \multirow{3}{*}{ Moya } & Dragomabin (53) & $\begin{array}{l}\text { Marine cyanobacterium } \\
\text { Lyngbya majuscula }\end{array}$ & Antiparasite toxicity & [45] \\
\hline & Almiramide B (54) & $\begin{array}{l}\text { Marine cyanobacterium } \\
\text { Lyngbya majuscule }\end{array}$ & Antitumor cytotoxicity & [14] \\
\hline & $\begin{array}{c}\text { Almiramides D-H } \\
(55-59)\end{array}$ & $\begin{array}{l}\text { Marine cyanobacterium } \\
\text { Oscillatoria nigroviridis }\end{array}$ & Antitumor cytotoxicity & {$[48]$} \\
\hline Mdyna & Viridamides A-B (61-62) & $\begin{array}{l}\text { Marine cyanobacterium } \\
\text { Oscillatoria nigro-Wiridis }\end{array}$ & $\begin{array}{l}\text { Antitrypanosomal activity } \\
\text { Antileishmanial activity }\end{array}$ & [49] \\
\hline \multirow[b]{2}{*}{ Br-Hmoya } & Veraguamides A (28) & $\begin{array}{l}\text { Marine cyanobacterium } \\
\text { Symploca cf. hydnoides }\end{array}$ & $\begin{array}{l}\text { Veraguamides A and C, } \\
\text { antitumor cytotoxicity }\end{array}$ & [40] \\
\hline & Viridamides K-L (63-64) & $\begin{array}{l}\text { Marine cyanobacteria, cf. } \\
\text { Oscillatoria margaritifera }\end{array}$ & Antitumor cytotoxicity & [13] \\
\hline $\begin{array}{l}\text { 2,4-dimethyl-9- } \\
\text { decynoic acid }\end{array}$ & Carmabins A (60) & $\begin{array}{l}\text { Marine cyanobacterium } \\
\text { Lyngbya majuscula }\end{array}$ & $\begin{array}{c}\text { Antimalaria against the W2 } \\
\text { chloroquine-resistant } \\
\text { malaria strain }\end{array}$ & [50] \\
\hline $\begin{array}{l}\text { 9-(chloromethylene)-6- } \\
\text { methyltetradec-4-en- } \\
\text { 13-ynoic acid }\end{array}$ & $\begin{array}{l}\text { Jamaicamide A-B } \\
\quad(65-66)\end{array}$ & $\begin{array}{l}\text { Marine Cyanobacterium } \\
\text { Lyngbya majuscula }\end{array}$ & not mentioned & {$[51-53]$} \\
\hline
\end{tabular}

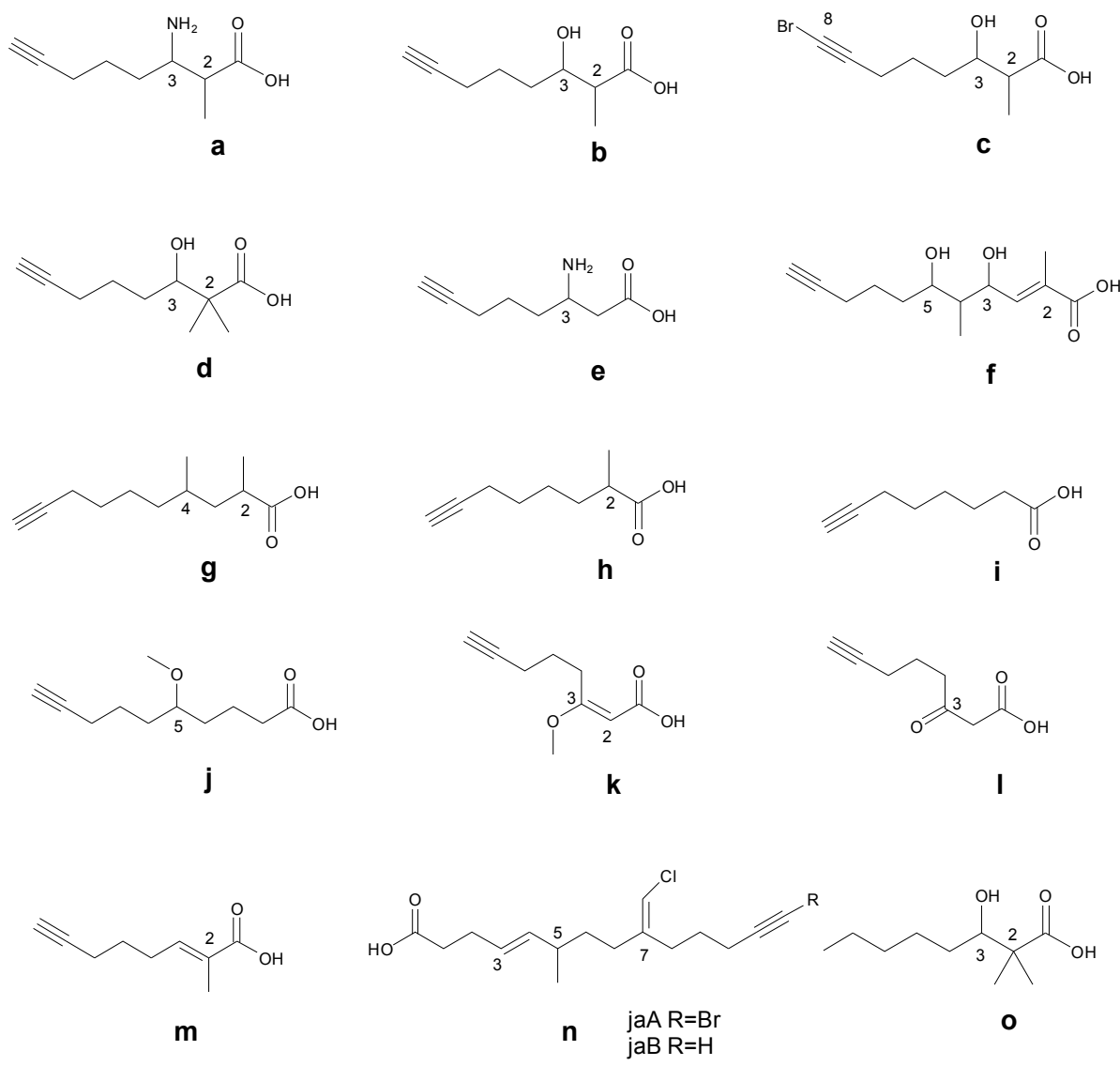

Figure 1. Structures of the terminal alkynyl fatty acyl moieties identified in cyclic/acyclic marine peptides. a. 3-amino-2-methyl-7-octynoicacid (Amoya); b. 3-hydroxy-2-methyloct-7-ynoic acid (Hmoya); c. bromine-containing 3-hydroxy-2-methyloct-7-ynoic acid (Br-Hmoya); d. 2,2-dimethyl-3hydroxy-7-octynoic acid (Dhoya); e. 3-amino-6-octyneoic acid (Aoy); f. 5,7-dihydroxy-2,6-dimethyldodec -2-en-11-ynoic acid (Dddd); g. 2,4-dimethyl-9-decynoic acid; h. 2-methyl-7-octynoic acid (Moya); i. 7-octynoic acid (Oya); j. 5-methoxydec-9-ynoic acid (Mdyna); k. 3-methoxy-2-en-7-octynoic acid; 1. 3-keto-7-octynoic acid; m. (E)-2-methyloct-2-en-7-ynoic acid; n. (4E,9E)-9- (chloromethylene)-6methyltetradec-4-en-13-ynoic acid; o. 2,2-dimethyl-3-hydroxy-7-octanoic acid (Dhoaa). 


\subsection{Cyclic Peptides with Dhoya Unit from Marine Cyanobacteria}

Cyclic peptides are representative secondary metabolites of cyanobacteria, and in recent years a number of structurally diverse terminal alkynyl-containing cyclic peptides have been found in marine cyanobacteria. The 2,2-dimethyl-3-hydroxy-7-octynoic acid (Dhoya) moiety appeared to be most frequently identified in the terminal alkynyl-containing cyclic peptides. The first two Dhoya unit-containing cyanobacterial cyclic depsipeptides, yanucamides A (1) and B (2, Table 1, Figure 2), were isolated from the lipid extract of a Lyngbya majuscula and Schizothrix sp. assemblage collected at Yanuca Island, Fiji, in 2000 [12]. Interestingly, the Dhoya unit had previously been found only in kulolide-1 (38) and kulokainalide-1 (39), metabolites isolated from the marine mollusk Philinopsis speciosa. Thus, the discovery of the yanucamides from a field-collected marine cyanobacterium substantiated the hypothesis that marine cyanobacteria are the probable source of the kulolides and their related metabolites. Both yanucamides A and B displayed strong brine shrimp toxicity (LD $\mathrm{LD}_{50}, 5 \mathrm{ppm}$ ). In 2001, Luesch et al. reported isolation and identification of two new cyclic depsipeptides, pitipeptolides A (3, Figure 2) and B, from a population of the marine cyanobacterium Lyngbya majuscula collected at Piti Bomb Holes, Guam [22]. Pitipeptolide A with a Dhoya unit and B with a reduced form of Dhoya unit, both showed potent in vitro cytotoxicity against LoVo cells with $\mathrm{IC}_{50}$ values of 2.25 and $1.95 \mu \mathrm{g} / \mathrm{mL}$, respectively; and also exhibited certain growth inhibition for Mycobacterium tuberculosis strains ATCC 25177 and ATCC 35818 in the diffusion susceptibility assay. Both compounds were also observed to increase elastase activity (2.76-fold and 2.55-fold, respectively, at $50 \mu \mathrm{g} / \mathrm{mL}$ ). Further, in 2011, Luesch et al. revisited larger collections of the same cyanobacterium and obtained additional analogs of pitipeptolides $A$ and $B$, as well aspitipeptolides $C$ (tetrahydro analog of 3) and D-F (4c, 5-6, Figure 2) [23]. Pitipeptolide A as the major metabolite in this series was reported to act as a feeding deterrent at natural concentrations against a range of marine grazers, suggesting that pitipeptolide A may play an important ecological role among these organisms [54]. Although pitipeptolides C-F were less potent than pitipeptolides A and B against HT-29 colon adenocarcinoma and MCF7 breast cancer cell lines, pitipeptolides $C$ and E showed similar antimycobacterial activities comparable to pitipeptolides A and B. Among them, pitipeptolide $\mathrm{F}$ exhibited the highest potency, but pitipeptolide D did not show activities against both mammalian and bacterial cells. As a result, it indicates that the activities of pitipeptolides are not strongly impacted by the Dhoya unit in the structure. Georgamide (7, Figure 2), another analog of pitipeptolides featuring Dhoya residue, was obtained from an Australian cyanobacterium Q66C5927 at the head of the King George River, Northwestern Australia [24].

In 2005, an assay-based screening program for anticancer compounds from the marine cyanobacterium Lyngbya semiplena collected from Papua New Guinea led to the discovery of four new depsipeptides: wewakpeptins A-D featured with Dhoya or its fully reduced form (Dhoaa, o) residues [31]. Intriguingly, wewakpeptins A (8a, Figure 2) and B were approximately 10-fold more toxic than $\mathrm{C}(9)$ and $\mathrm{D}$, with an $\mathrm{LC}_{50}$ of approximately $0.4 \mu \mathrm{M}$ to NCI H-460 human lung tumor and mouse neuroblastoma cells. These cyclic depsipeptides most likely derive from a nonribosomal polypeptide synthetase (NRPS) pathway, and thus, the structural variation of wewakpeptins is intriguing and might suggest that adenylation domains with relaxed substrate specificity are involved in their biosynthesis [31]. Mantillamide (10), and dudawalamide A (11) featured with Dhoya residues were obtained from the marine cyanobacterium Lyngbya sp. because of their biological activity to cancer cells or malaria parasites, and they were able to be identified in a rapid manner using an annotation program developed from tandem mass spectra called MS-CPA available as a web tool (http://lol.ucsd.edu/ms-cpa_v1/Input.py) [25]. Isolation of a new cyclic depsipeptide, guineamide G (12) was reported in 2011 from the marine cyanobacterium Lyngbya majuscula, collected from Papua New Guinea. Guineamide $G$ was the only cyclic depsipetide featuring Dhoya residue in the series of guineamides, which showed potent brine shrimp toxicity and moderate cytotoxicity to a mouse neuroblastoma cell line with $\mathrm{LC}_{50}$ value of $2.7 \mu \mathrm{M}$ [26]. In 2011, Paul et al. reported isolation and identification of cocosamides A (13) and B (14) from the lipophilic extract of a collection of 
Lyngbya majuscula from Cocos Lagoon, Guam [27]. Cocosamide A consisting of Dhoea (a reduced form of Dhoya residue) was less potent than cocosamide B (featuring Dhoyaresidue) against HT-29 cells with $\mathrm{IC}_{50}$ values of 24 and $11 \mu \mathrm{M}$, respectively, indicating the presence of Dhoya moiety may have a slight effect on the cytotoxicity. In 2012, the family of viequeamides A-F was discovered from a shallow subtidal collection of a cyanobacterium (Rivularia sp.) near the island of Vieques, Puerto Rico, among which viequeamides A-B (15-16) and E-F (17-18, Figure 2) are 2,2-dimethyl-3-hydroxy-7-octynoic acid (Dhoya)-containing cyclic depsipeptides [28]. Intriguingly, viequeamide A was found to be the most active ( $\mathrm{IC}_{50}=60 \pm 10 \mathrm{nM}$ ) against $\mathrm{H} 460$ human lung cancer cell line, whereas the other viequeamides with quite similar structures were inactive.

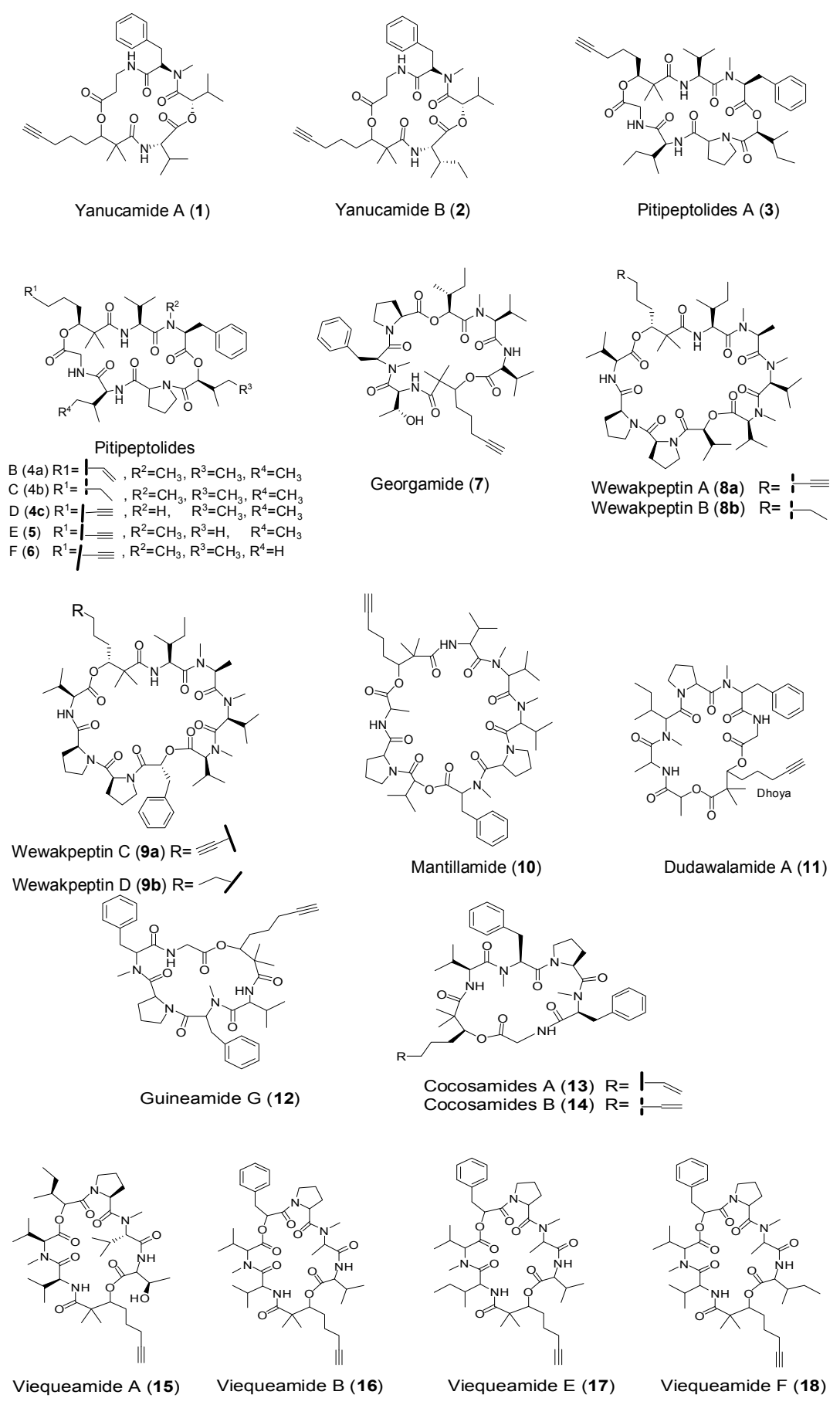

Figure 2. Structures of cyclic peptides with Dhoya residue from marine cyanobacteria. 


\subsection{Cyclic Peptides with Amoya Unit from Marine Cyanobacteria}

Malevamide C (19, Table 1, Figure 3), as the first reported 3-amino-2-methyl-7-octynoic acid (Amoya)-containing cyanobactrial peptide, was obtained from a cyanobactrium Symplocalaete-viridis collected in waters adjacent to AlaMoana Beach Park, Hawaii in 2000. The unusual $\beta$-amino acid residue, Amoya, was only previously identified in onchidin, a cyclic depsipeptide isolated from a marine mollusk Onchidium spp. [32]. However, malevamide $C$ did not display potent cytotoxicity against a variety of cancer cell lines. In 2003, another Amoya-containing cyclic depsipeptide, guineamide C (20, Figure 3) was discovered by William Gerwick's group from a Papua New Guinea collection of the marine cyanobacterium Lyngbya majuscula. As malevamide $\mathrm{C}$, guineamide $\mathrm{C}$, only exhibited moderate cytotoxicity against neuroblastoma cells with an $\mathrm{IC}_{50}$ value of $16 \mu \mathrm{M}$ [33]. Meanwhile, Williams et al. reported discovery of ulongapeptin (21) featuring Amoya residue, isolated from a dark reddish-black clump of cyanobacterium, designated VP755 collected at Ulong Channel in Palau. Interestingly, ulongapeptin showed strong cytotoxicity against $\mathrm{KB}$ cells at an $\mathrm{IC}_{50}$ value of $0.63 \mu \mathrm{M}$ [34]. Just recently, two new cyclic depsipeptides, companeramides A (22) and B (23) containing Amoya unit, were obtained from a marine cyanobacterial assemblage comprising a small filament Leptolyngbya species, from Coiba Island, Panama. It is interesting to note that companeramides A and B showed high nanomolar in vitro antiplasmodial activity, though not quite cytotoxic to human cancer cell lines [35].

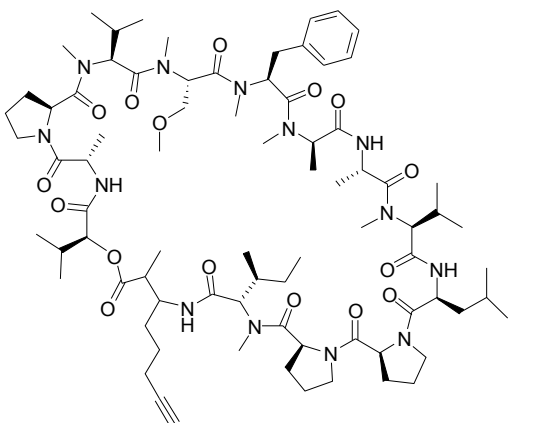

Malevamide C (19)

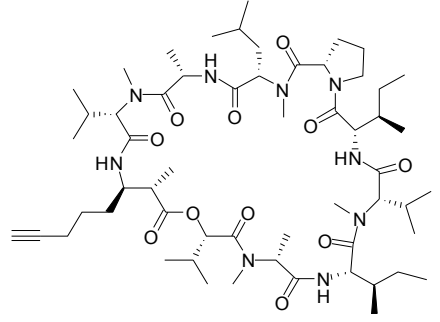

Companeramides A (22)

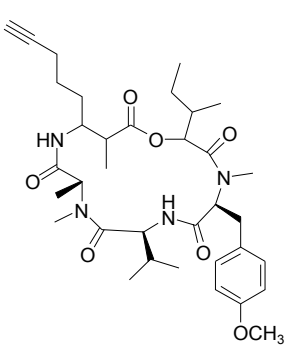

Guineamide C (20)

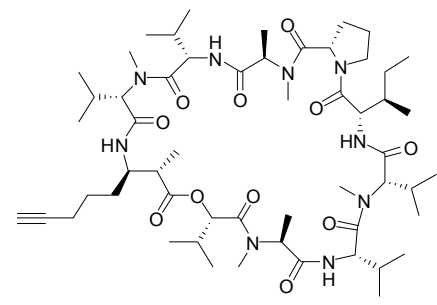

Companeramides B (23)

Figure 3. Structures of cyclic peptides with Amoya residue from marine cyanobacteria.

\subsection{Cyclic Peptides with Hmoya/Br-Hmoya/Dddd Units from Marine Cyanobacteria}

While the 3-hydroxy-2-methyloctynoic acid (Hmoya) residue was initially identified in the molluscan metabolite onchidin B [11,36], antanapeptin A (24) and antanapeptin D (25, Figure 4) are the first two cyclic peptides containing Hmoya residue, obtained from a cyanobacterium Lyngbya majuscule collected from Antany Mora, Madagascar [37]. The antanapeptins were observed inactive in brine shrimp toxicity, sodium channel modulation, and antimicrobial bioassays. Subsequently, Sitachitta et al. in 2006, reported isolation and identification of three new cyclic peptides, trungapeptins A (26)-C, containing Hmoya residue, 3-hydroxy-2-methyl-7-octenoic acid (Hmoea), and 3-hydroxy-2-methyl-7-octanoic acid (Hmoaa) residues, respectively [38]. The relative 
stereochemistry of Hmoya residue of trungapeptin A was determined to be syn configuration between H-2 and H-3 by measurement of homonuclear coupling constant as well as comparison of the literature value. The absolute stereochemistry of the Hmoya unit was established as $2 S, 3 R$ by Mosher's analysis. Intriguingly, herein the stereochemistry of the Hmoya unit is identical to that of kulomo'opunalides [30], but is diastereomeric to that of onchidin $\mathrm{B}(2 R, 3 R)$. Unlike antanapeptins, trungapeptin A exhibited potent brine shrimp toxicity and ichthyotoxicity at $10 \mathrm{ppm}$ and $6.25 \mathrm{ppm}$, respectively. However, it was inactive against $\mathrm{KB}$ and LoVo cells at $10 \mu \mathrm{g} / \mathrm{mL}$. In 2009, a new Hmoya-containing analog of trungapeptin A, hantupeptin A (27, Figure 4) was discovered from the marine cyanobacterium Lyngbya majuscula from PulauHantuBesar, Singapore [39]. The absolute configuration at C-3 was determined to be $S$ by Mosher's analysis following methanolysis of hantupeptin A and isolation of the Hmoya fragment. However, the stereochemistry at C-3 of the Hmoya unit in hantupeptin A is different from that of trungapeptin A. Further, hantupeptin A afforded both brine shrimp toxicity at $10 \mathrm{ppm}$ and strong cytotoxicity against the leukemia cell line MOLT- 4 with an $\mathrm{IC}_{50}$ value of $32 \mathrm{nM}$.

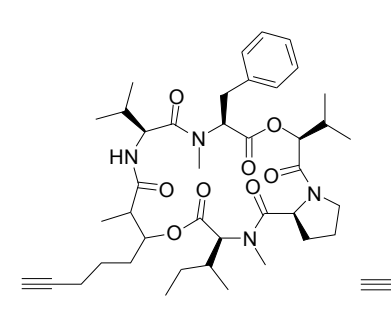

Antanapeptins A (24)

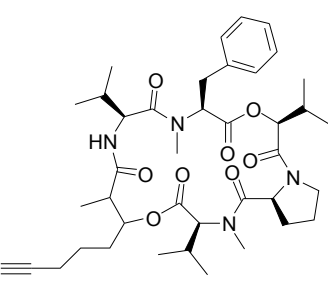

Antanapeptins D (25)

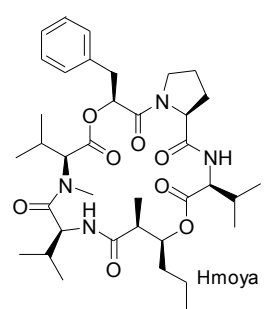

Trugapetin A (26)

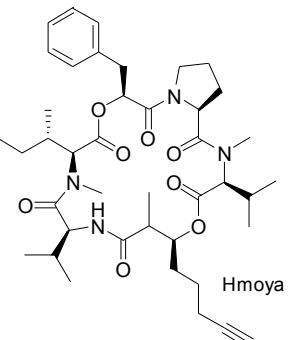

Hantupeptin A (27)

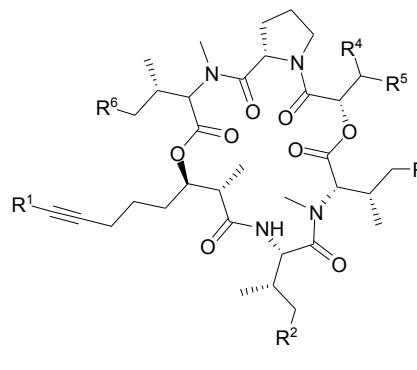

Veraguamides

$R^{3} A$ (28) $R^{1}=B r, R^{2}=H, R^{3}=H, R^{4}=E t, R^{5}=M e, R^{6}=H$ B (29) $R^{1}=B r, R^{2}=H, R^{3}=H, R^{4}=M e, R^{5}=M e, R^{6}=H$ C (30) $R^{1}=H, R^{2}=H, R^{3}=H, R^{4}=E t, R^{5}=M e, R^{6}=H$ D (31) $R^{1}=H, R^{2}=H, R^{3}=H, R^{4}=E t, R^{5}=M e, R^{6}=M e$ E (32) $R^{1}=H, R^{2}=M e, R^{3}=M e, R^{4}=E t, R^{5}=M e, R^{6}=H$ F (33) $R^{1}=H, R^{2}=H, R^{3}=H, R^{4}=P h, R^{5}=M e, R^{6}=H$ $\mathrm{H}$ (34) $\mathrm{R}^{1}=\mathrm{H}, \mathrm{R}^{2}=\mathrm{H}, \mathrm{R}^{3}=\mathrm{H}, \mathrm{R}^{4}=\mathrm{Me}, \mathrm{R}^{5}=\mathrm{Me}, \mathrm{R}^{6}=\mathrm{H}$

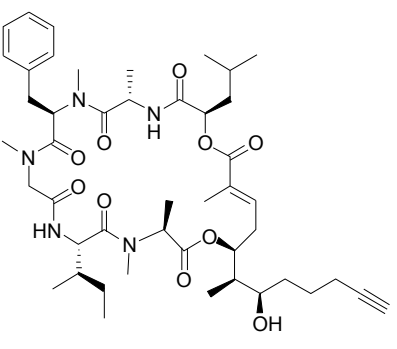

Palau'amide (35)

Figure 4. Structures of cyclic peptides with Hmoya/Br-Hmoya/Dddd residue from marine cyanobacteria.

In 2011, the Luesch group and Gerwick group coincidently reported isolation and identification of a series of peptides featured with Hmoya and its derived residues, veraguamides A-F (28-33), from a cyanobacterium Symploca cf. hydnoides at Cetti Bay, Guam [40], and veraguamides H (34), I-L from the marine cyanobacterium cf. Oscillatoria margaritifera at the Coiba National Park, Panama [13], respectively. Among them, veraguamides $\mathrm{A}$ and $\mathrm{B}$ are 8-bromo-3-hydroxy-2-methyl-7-octynoic acid (Br-Hmoya) moiety-containing cyclic peptides, while veraguamides $\mathrm{K}$ and L (63-64) are Br-Hmoya-containing linear peptides (more in Section 3). It is interesting to note that veraguamides D and $\mathrm{E}$ were five-fold more potent than their related congener veraguamide $\mathrm{C}$ against HT29 colorectal and HeLa cervical adenocarcinoma cells, while veraguamides A, B and F were inactive againstthese cancer cell lines. Surprisingly, veraguamide A exhibited strong potency in the H-460 cytotoxicity assay $\left(\mathrm{LD}_{50}=141 \mathrm{nM}\right)$, but veraguamides $\mathrm{B}, \mathrm{C}, \mathrm{K}$ and $\mathrm{L}$ were much less active.

Palau'amide (35, Figure 4) is a unique terminal alkynyl-containing cyclic depsipeptide, consisting of a novel polyketide unit, 5,7-dihydroxy-2,6-dimethyldodec-2-en-11-ynoic acid (Dddd), which was obtained from a Lyngbya sp. from Palau. Palau'amide showed strong cytotoxicity against KB cells with an $\mathrm{IC}_{50}$ value of $13 \mathrm{nM}$ [41]. 


\subsection{Cyclic Peptides from Marine Mollusks}

Onchidin (36, Figure 5) as the first report of a dimeric depsipeptide from a mollusc, featured with two 3-amino-2-methyl-7-octynoicacid (Amoya, a) residues, was obtained from the pulmonate mollusk Onchidium sp. collected off New Caledonian 1994 [11]. Onchidin B (37) isolated and identified along with onchidin from the same extract, shares quite similar structural features with onchidin. Interestingly, onchidin B featured with two 3-hydroxy-2-methyloct-7-ynoic acid (Hmoya, b) does not have a $C_{2}$ axis of symmetry as does onchidin, due to the presence of the two enantiomers of proline that renders the two halves of the molecule different [36]. Onchidin and onchidin B exhibited identical cytotoxicity against P-388 murine leukemia cells $\left(\mathrm{IC}_{50}=8 \mu \mathrm{g} / \mathrm{mL}\right)$ and $\mathrm{Kb}$ human epidermoid carcinoma cells $\left(\mathrm{IC}_{50}=8 \mu \mathrm{g} / \mathrm{mL}\right)$, respectively.

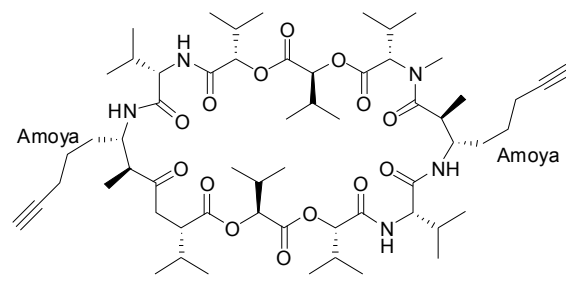

Onchidin (36)

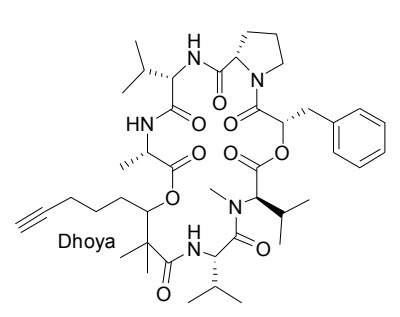

Kulolide-1 (38)

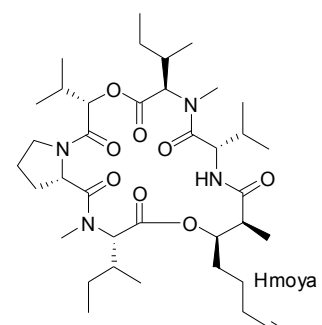

Kulomo'opunalide 2 (41)

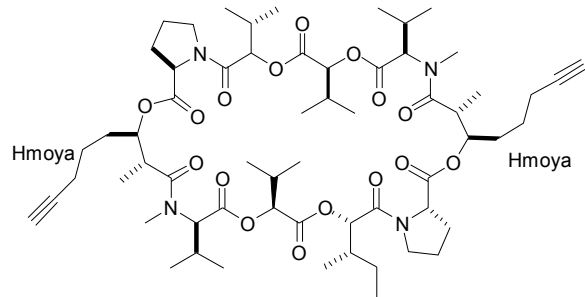

Onchidin B (37)

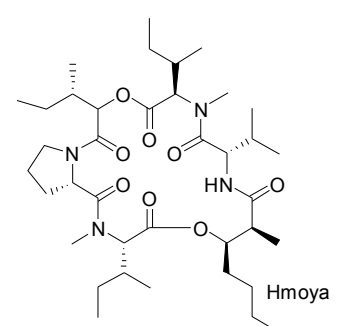

Kulomo'opunalide-1 (40)

Kulokainalide-1 (39)

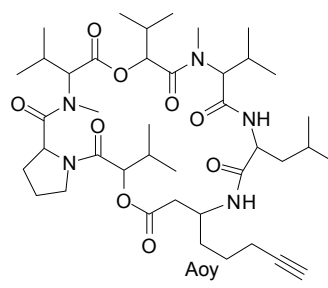

Dolastatin $17(\mathbf{4 2})$

Figure 5. Structures of cyclic peptides with Amoya/Hmoya/Dhoya/Aoy residue from marine mollusks.

A cephalaspidean mollusk, Philinopsis speciosa Pease, 1860 collected off North Shore, Oahu's (Hawaiian Islands) Shark Bay, afforded the first 2,2-dimethyl-3-hydroxy-7-octynoic acid (Dhoya)-containing cyclic depsipeptide, kulolide-1 (38, Figure 5) [29]. Kulolide-1was active against L-1210 leukemia cells and P388 murine leukemia cells at IC $_{50}$ values of 0.7 and $2.1 \mu \mathrm{g} / \mathrm{mL}$, respectively. Along with kulolide-1, three other terminal alkynyl-containing cyclic depsipeptides, kulokainalide-1 (Dhoya, 39), kulomo'opunalide-1 (Hmoya, 40) and kulomo'opunalide-2 (Hmoya, 41), were also discovered from the same sample of the cephalaspidean mollusk, Philinopsis speciosa [30].

3-amino-6-octyneoic acid (Aoy, e) as an unprecedented terminal alkynyl moiety, was only identified in a novel cyclic depsipeptide, dolastatin 17, isolated from a sea hare Dolebella auricularia [12]. Dolastatin 17 (42, Figure 5) displayed significant growth-inhibitory activity against OVCAR-3 (GI50 $0.67 \mu \mathrm{g} / \mathrm{mL}$ ), SF-295 (GI50 $0.55 \mu \mathrm{g} / \mathrm{mL}$ ), NCI-H460 (GI50 $0.74 \mu \mathrm{g} / \mathrm{mL})$, KM20L (GI50 $0.45 \mu \mathrm{g} / \mathrm{mL}$ ) human cancer cell lines [42]. 


\section{Acyclic Lipopeptides Containing Terminal Alkyne from Marine Cyanobacteria}

It is interesting to note that many linear peptides have also been found to possess the terminal alkynyl fatty acyl moieties, including 2,4-dimethyl-9-decynoic acid (g), 2-methyl-7-octynoic acid (Moya, h), 7-octynoic acid unit (Oya, i), 5-methoxydec-9-ynoic acid (Mdyna, j), 3-methoxy-2-en-7-octynoic acid (MeO-Oya-2-ene, k), 3-keto-7-octynoic acid (1), and (E)-2-methyloct-2-en-7-ynoic acid (m), which are different from that of cyclic peptides, except for Hmoya and Br-Hmoya residues present in both linear and cyclic veraguamides (Table 1). In addition, an acyclic amide-like secondary metabolite from the marine cyanobacteria Lyngbya majuscula, termed jamaiapcamides A, has provided an alkynyl bromide, vinyl chloride, $\beta$-methoxyeneone moiety (n) to the terminal alkynyl-containing peptides.

All the terminal alkynyl-containing linear peptides were solely discovered from marine cyanobacteria. In 2000, Luesch et al. reported the isolation and identification of six new linear peptides, apramides A-G (Figure 6), from the marine cyanobacterium Lyngbya majuscule collected at Apra Harbor, Guam [43]. Apramides A (43), D (45) and G (46) are Moya-containing acylic peptides, while apramides $\mathrm{C}$ and $\mathrm{F}$ consist of 2-methyl-7-octenoic acid moiety (Moea) in their structures. Apramides B (44) and $\mathrm{E}$ (47) possess a 7-octynoicacid unit (Oya) in lieu of the Moya moiety, and the rest of the structures are identical to apramides A and D, respectively. Apramides A-G was inactive in cytotoxic, antibacterial, antifungal assays, but apramide A exhibited stimulating elastase activity.

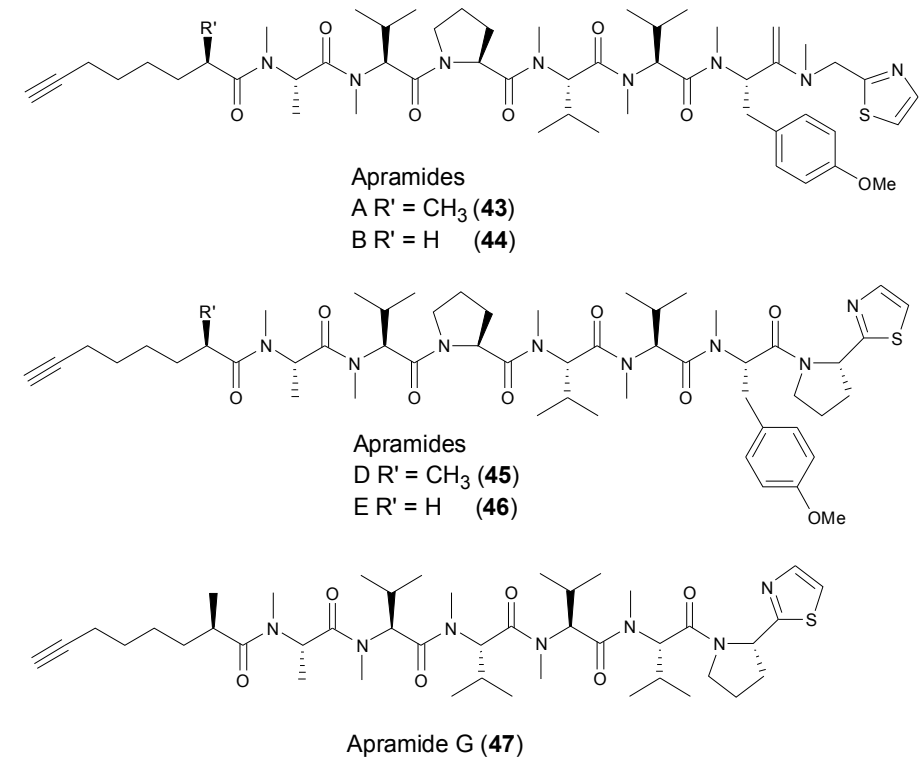

Figure 6. Structures of linear peptides (apramides A-G) from marine cyanobacteria.

Dragonamides are a family of structurally close linear peptides composing of a variety of terminal alkynyl units (Figure 7). Several separate Panamanian collections of Lyngbya majuscule Gomont afforded dragonamides A, B (48-49) and E [44-46], while the collection of brown Lyngbya polychroa from Hollywood Beach, Fort Lauderdale, FL led to the discovery of dragonamides C and D [47]. Dragonamides A and B contain a terminal 2-methyl-7-octynoic acid unit (Moya), whereas dragonamides $\mathrm{C}, \mathrm{D}$ and $\mathrm{E}$ (50-52) possess three different terminal acetylene units, 3-methoxy-2-en-7-octynoic acid (k), 3-keto-7-octynoic (1) (E)-2-methyloct-2-en-7-ynoic acid (m), respectively, which were not previously reported from marine peptides. Dragonamides did not exhibit strong activities against a variety of tumor cell lines, except dragonamides A and E which showed moderate in vitroactivity against leishmaniasis. Along with dragonamides $A$ and $B$, another terminal Moya-containing linear peptide, dragomabin (53, Figure 7), was isolated and identified in 2007, from a Panamanian strain of the marine cyanobacterium Lyngbya majuscula [45]. Dragomabin possesses the best differential toxicity between parasite and mammalian cells, with $\mathrm{IC}_{50}$ value of 
$6.0 \mu \mathrm{M}$ against the W2 chloroquine-resistant malaria strain and $\mathrm{IC}_{50}$ value of $182.3 \mu \mathrm{M}$ against Vero cells (kidney epithelial cells).

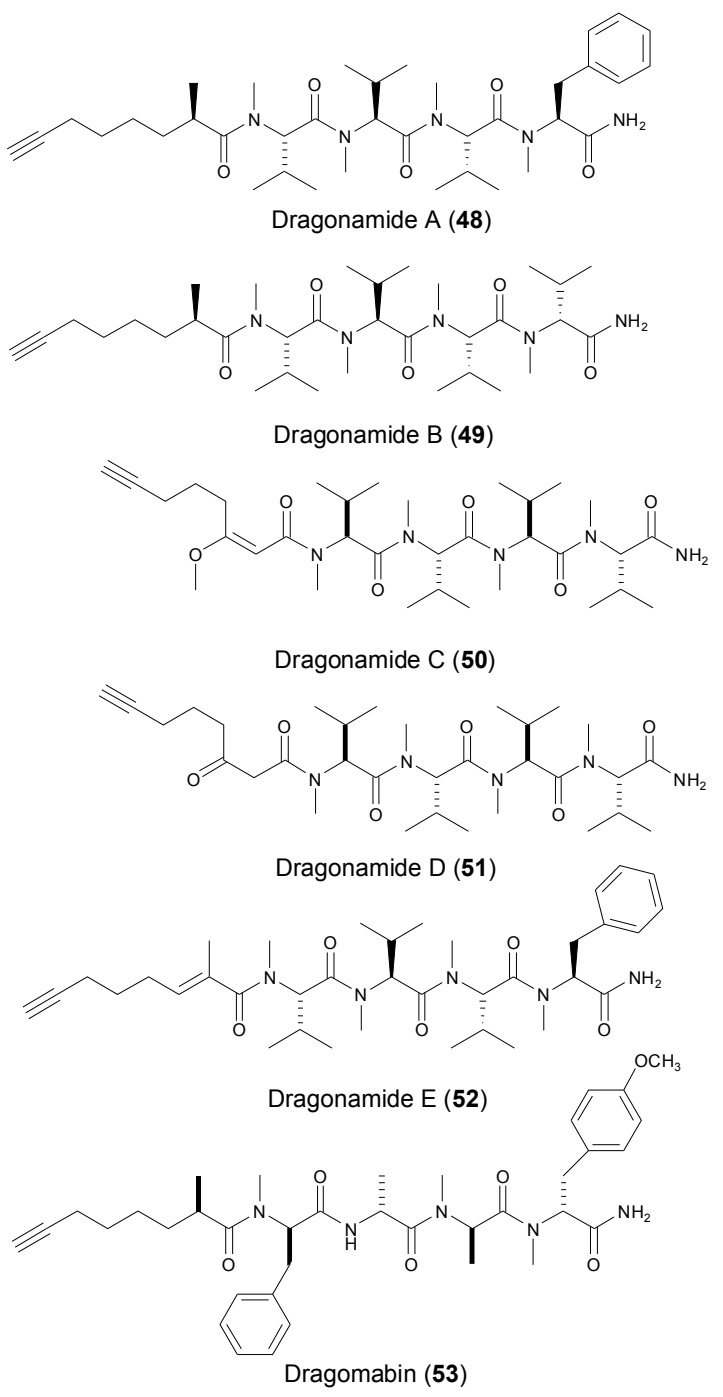

Figure 7. Structures of linear peptides (dragonamides A-E, dragomabin) from marine cyanobacteria.

In 2010, Linington et al. reported the isolation and identification of a series of terminal fatty acyl units-containing linear peptides, almiramides $\mathrm{A}-\mathrm{C}$, from a Panamanian strain of the marine cyanobacterium Lyngbya majuscule [14]. Among them, almiramide B (54) is featured with a terminal Moya unit (Figure 8), whereas almiramide $C$ contains a reduced form of Moya as a 2-methyloct-7-enoic acid residue. Biological evaluation of these three compounds showed that almiramides $\mathrm{B}$ and $\mathrm{C}$ possessed good selectivity between parasite and mammalian cells with strong in vitro antiparasitic activity against leishmania $\left(\mathrm{IC}_{50}=2.4\right.$ and $1.9 \mu \mathrm{M}$, respectively), and weak activity against Vero cells $\left(\mathrm{IC}_{50}=52.3\right.$ and $33.1 \mu \mathrm{M}$, respectively). Just recently, a series of new terminal Moya-containing linear peptides, almiramides D-H (55-59) along with known almiramide B (Figure 8), were isolated and identified from a cyanobacterium sample of Oscillatoria nigroviridis collected at the Colombian Caribbean Sea [48]. Intriguingly, two structurally representative almiramides B and D showed mild toxicity against five human tumor cell lines, but high toxicity against the gingival fibroblast cell line was used as reference to evaluate selectivity against tumor cell lines compared with primary cell line.

Two novel terminal fatty acyl-containing linear peptides, carmabins A (60) and B were discovered from a collection of the marine cyanobacterium Lyngbya majuscule at Barbara Beach (Spanish Waters), 
Curacao, Netherlands Antilles in 1998 [50]. Carmabin A (Figure 9) is featured with a novel terminal 2,4-dimethyl-9-decynoic acid residue, but in carmabin B, the acetylene functional group is replaced with a methyl ketone. To the best of our knowledge, carmabin $\mathrm{A}$ is the only reported compound containing a 2,4-dimethyldec-9-ynoic acid moiety. Carmabin A exhibited moderate cytotoxicity to Vero cells $\left(\mathrm{IC}_{50}=9.8 \mu \mathrm{M}\right)$, and mild activity against the W2 chloroquine-resistant malaria strain $\left(\mathrm{IC}_{50}=4.3 \mu \mathrm{M}\right)$.

$$
\begin{aligned}
& \mathrm{D}(\mathbf{5 5}) \mathrm{R}^{1}=\mathrm{Me}, \mathrm{R}^{2}=\mathrm{Me}, \mathrm{R}^{3}=\mathrm{Me} \\
& \mathrm{E}(\mathbf{5 6}) \mathrm{R}^{1}=\mathrm{Me}, \mathrm{R}^{2}=\mathrm{Me}, \mathrm{R}^{3}=\mathrm{H} \\
& \mathrm{F}(\mathbf{5 7}) \mathrm{R}^{1}=\mathrm{CH} \mathrm{OH}_{2} \mathrm{OH}, \mathrm{R}^{2}=\mathrm{Me}, \mathrm{R}^{3}=\mathrm{Me} \\
& \mathrm{G} \text { (58) } \mathrm{R}^{1}=\mathrm{Me}, \mathrm{R}^{2}=\mathrm{H}, \mathrm{R}^{3}=\mathrm{Me} \\
& \mathrm{H}(\mathbf{5 9}) \mathrm{R}^{1}=\mathrm{H}, \mathrm{R}^{2}=\mathrm{Me}, \mathrm{R}^{3}=\mathrm{Me}
\end{aligned}
$$

Figure 8. Structures of linear peptides (almiramide B, D-H) from marine cyanobacteria.

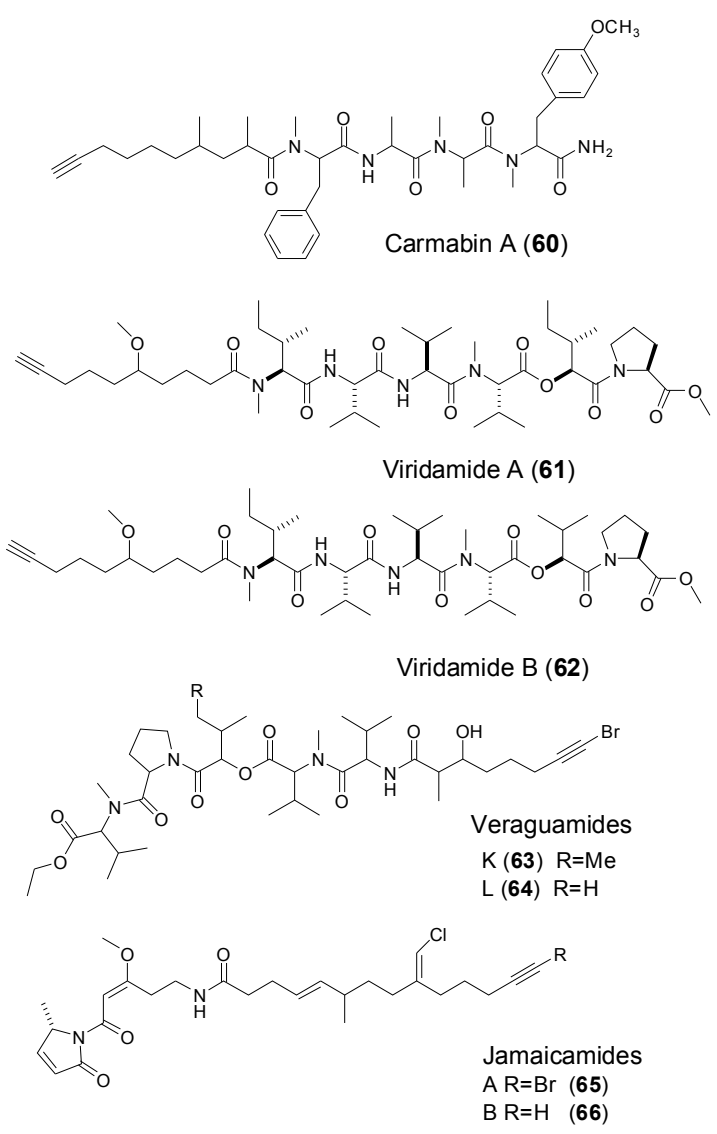

Figure 9. Structures of linear peptides (carmabin A, viridamide A-B, veraguamides $\mathrm{K}$ and $\mathrm{L}$, and jamaicamides $\mathrm{A}-\mathrm{B})$ from marine cyanobacteria. 
In 2008, Simmons et al. reported discovery of two new linear peptides, viridamides A and B (61-62, Figure 9) isolated from the marine cyanobacterium Oscillatoria nogroviridis [51] (Figure 9), whose structures contain a novel terminal 5-methoxydec-9-ynoic acid moiety (Mdyna). Viridamide A displayed antitrypanosomal activity ( $\mathrm{IC}_{50} 1.1 \mu \mathrm{M}$ to Trypanosoma cruzi) and antileishmanial activity ( $\mathrm{IC}_{50} 1.5 \mu \mathrm{M}$ to Leishmania mexicana).

\section{Different Methods to Determine the Absolute Configuration of Different Alkynyl Fragments}

\subsection{Amoya (a)}

Determination of stereochemistry of the 3-amino-2-methyl-7-octynoic acid (Amoya, a) residue in the cyclic depsipeptides was established using differential methods such as NMR or Marfey's analysis. The configuration of an Amoya unit in onchidin was found to be threo through analysis of the NOE data and their coupling constants for critical protons, which indicated the relative stereochemistry of the pentine side chain on the same side as the neighboring MeVal and Val isopropyl groups. As a result, the absolute configuration of an Amoya unit in onchidin was determined to be $7 S, 9 S$ [11]. The stereochemistry of the Amoya unit in ulongapeptin was determined using the synthetically saturated 3-amino-2-methyloctanoic acid C-2 diastereomers ( $2 R, 3 R$ and $2 S, 3 R)$ as standards for Marfey's analysis. Comparison with the derivatized hydrogenated hydrolysate of ulongapeptin established the absolute configuration of the Amoya as 2S, 3S [34]. Surprisingly, the absolute configuration of the Amoya unit in companeramides A (22) and B (23) was determined to be $2 S, 3 R$ using the method of Marfey's analysis in comparison with synthetically saturated 3-amino-2-methyloctanoic acid C-2 diastereomeric (2R, 3R and $2 S, 3 R)$ standards [35].

\subsection{Hmoya (b)}

Determination of stereochemistry of 3-hydroxy-2-methyloct-7-ynoic acid (Hmoya) was first accomplished in the work of identification of onchidin B [36]. As beginning of the work, all four possible stereoisomers of Hmoya were synthesized in a diastereo selective mode. However, direct comparative analysis of the methyl esters of the four synthetic standards with the methyl ester of the natural Hmoya hydrolyzed from onchidin B using chiral gas chromatography (GC) and HPLC was not successful due to a separation issue. Consequently, the problem was overcome by derivation of the four hydroxy esters with $(-)-(R)-\alpha$-methoxy- $\alpha-(9$-anthryl) acetic acid as well as the natural Hmoya component to obtain good resolution of the four synthetic stereoisomers in LC-MS analysis, which indicated that the absolute configuration of Hmoya moiety in onchidin B was $2 R$, $3 R$. The stereochemistry of the Hmoya unit in Kulomo'opunalide-1 (40) and kulomo'opunalide-2 (41) was initially worked on comparison of chemical shifts of the $p$-bromobenzoyl derivatized synthetic standards with the derivatized natural Hmoaa (hydrogenated form of Hmoya) in ${ }^{1} \mathrm{H}$ NMR spectra to provide the relative stereochemistry of $2 S^{*}, 3 R^{*}$. Comparison of retention time and co-injection of the standards with hydrolyte of the hydrogenated (40) and (41) confirmed the absolute stereochemistry of the Hmoya unit as $2 S, 3 R$ [30], which is surprisingly different from $2 R, 3 R$ of the Hmoya unit in onchidin B. Interestingly, the absolute configuration of the Hmoya unit in trungapeptin A (26) was determined to be $2 S, 3 R$ by application of the J-based configuration analysis as well as Mosher's method [38]. Further, the stereochemistry of Hmoya in hantupeptin A (27) was determined to be $S$ at C-3 using Mosher's analysis, but the configuration at C-2 was not established [39]. In addition, the absolute configuration of the Br-Hmoya unit in veraguamide A (28) was also determined to be $2 S, 3 R$ identical to that of trungapeptin A using the J-based configuration analysis as well as the Mosher's method subjected to the linear veraguamide A following methanolysis of 28 [40].

\subsection{Dhoya (d)}

Determination of absolute configuration of 2,2-dimethyl-3-hydroxy-7-octynoic acid (Dhoya) residue was initially achieved in the structure elucidation of kulolide-1 (38), which was treated 
with $\mathrm{NaOMe}$ to release the free hydroxyl functional group in the Dhoya-containing fragment, followed by Mosher's analysis to reveal the R-configuration at C-3 of Dhoya [29]. Interestingly, the stereochemistry of the Dhoya unit in kulokainalide- 1 was determined to be $3 S$ by comparing the values of optical rotation of Dhoaa (saturated form of Dhoya) residues obtained from the acid hydrolysates of both hydrogenated kulolide-1 and kulokainalide-1 [30]. Further, Ye et al. achieved a total synthesis of yanucamide A to confirm the absolute configuration of Dhoya to be the same (3S) as in kulokainalide-1 [55]. The stereochemistry of the Dhoya unit in pitipeptolide A (3) was also revealed as $3 S$ using the optical rotation data of the obtained Dhoaa unit [22]. Interestingly, the absolute configuration of the Dhoya unit in wewakpeptin A (8) was determined to be $R$ by chiral GC-MS analysis of the hydrogenated Dhoya in 8 possessing the same retention time as synthetic $R$-Dhoaa [31]. The chiral center of Dhoya residue in cocosamide B (14), was suggested to possess the same $3 S$ configuration as in pitipeptolide A, by comparison of the NOE correlations of specific protons observed for Dhoya as well as related protons in the structures of cocosamide B and pitipeptolide A [27]. The configuration of Dhoya residue in viequeamide A was revealed to be $S$ by chiral GC-MS analysis of the synthetic standards and the obtained natural Dhoya unit [28].

\subsection{Moya $(\boldsymbol{h})$}

The 2-methyl-7-octynoic acid (Moya, h) unit is the most frequently identified terminal alkynyl residue in the linear peptides. The absolute configuration at C-2 in apramides was proposed to be $R$ based on the negative contribution of the C-2 stereocenter to the molar optical rotation of the molecule [50], because it is known for a closely related model compound that the $2 S$ epimer gives a more positive rotation in $\mathrm{CHCl}_{3}$ than the corresponding epimer with $\mathrm{R}$ configuration in the lipid chain [56]. The stereochemistry of Moya residue in dragonamide A was initially determined to be $R$, which was inferred by comparison of optical rotation data of 2-methyloctanoic acid obtained from hydrolyte of hydrogenated dragonamide A with literature values of other 2-methylalkanoic acids $[57,58]$. Subsequently, the later total synthesis of dragonamide A has led to a reassignment of the configuration as $S$ at the stereogenic center of the Moya unit of the molecule [16]. Further, dragonamide B and dragomabin were isolated with dragonamide A from a Panamanian collection of Lyngbya majuscule Gomont, while the NMR and optical rotation data for this dragonamide A closely match the $2 S$ synthetic product, but differ significantly from the $2 R$ synthetic product [45]. Therefore, it was concluded that dragonamide A, dragonamide B, and dragomabin all contain 2S-methyloct-7-ynoic acid. The stereochemistry at C-2 of Moya residue in almiramides B and C was investigated by comparison of commercial standards with obtained natural Moya derivatives using GC-MS, which was determined to be $R$ configuration [46], surprisingly opposite to the absolute configuration of the Moya unit in dragonamides.

\subsection{Other Special Fragments}

Determination of stereochemistry of 5,7-dihydroxy-2,6-dimethyldodec-2-en-11-ynoic acid (Dddd, f) residue in Palau'amide was a bit complex, due to an inter-converting mixture of rotamers around these stereocenters of Dddd. With the secured NMR assignments for the two major conformers of Palau'amidein $\mathrm{CDCl}_{3}$ (C-R1/-R2), subsequent $\mathrm{NOE}$ experiments recorded in $\mathrm{CDCl}_{3}$ revealed a strong correlation between $\mathrm{H}-40$ and $\mathrm{H}-46$ that indicated the erythro configuration of C-38 and C-39. The Mosher's analysis of the absolute configuration of C-39 was carried on the $\alpha$-methoxy phenyl acetic acid (MPA) derivatives of Palau'amide. Comparison of the $\Delta \delta^{R S}$ values for these derivatives established the $R$ configuration of C-39 [41]. While the configuration of C-37 could not be rigorously established by chemical means, analysis of molecular models in conjunction with NOE data suggested an S-configuration for this chiral center. The double bond configuration of 3-methoxy-2-en-7-octynoic acid $(\mathbf{k})$ in dragonamide $\mathrm{C}$ and that of 2-methyloct-2-en-7-ynoic acid $(\mathbf{m})$ in dragonamide $\mathrm{E}$, were both assigned as E-geometry by NOE analysis $[47,48]$. 


\section{Conclusions}

A number of structurally intriguing peptides containing diverse terminal alkynyl fatty acyl residues, such as Dhoya, Hmoya, Amoya, Aoy, Moya, etc., have been found in multiple marine organisms, especially marine mollusk and cyanobacteria. In 1998, a study about the biological origin of Dhoya-containing cyclic depsipeptide, kulolide-1, by Scheuer and coworkers showed that the marine mollusk Philinopsis speciosa preyed on the herbivorous sea hare Stylocheilus longicaudus that is well recognized to possess the predator-prey relationship with cyanobacteria [30]. Interestingly, Scheuer and coworkers succeeded in isolating kulolide-1 from sea hare Stylocheilus longicaudus, which suggests that kulolide-1 discovered from P. speciosa is possibly accumulated from its prey Stylocheilus longicaudus, known to sequester secondary metabolites from its diet of mat-forming cyanobacteria [29]. Thus, similarity among the terminal alkynyl-containing cyclic peptides is suggestive that this intriguing structure family of metabolites in fact originates in cyanobacteria. Interestingly, all the terminal alkynyl fatty acyl moieties identified in the linear peptides were solely discovered as the constituents of metabolites of marine cyanobacteria.

Overall, many of these terminal alkynyl-containing peptides have shown a variety of biological functions as antitumor, antibacterial and antimalarial activities. Intriguingly, some of them with minor structural variations have presented different biological effects. For example, viequeamide A was found to be the most active ( $\mathrm{IC}_{50}=60 \pm 10 \mathrm{nM}$ ) against $\mathrm{H} 460$ human lung cancer cell line, whereas the other viequeamides with quite similar structures were inactive; hantupeptin A exhibited strong cytotoxicity against the leukemia cell line MOLT- 4 with an $\mathrm{IC}_{50}$ value of $32 \mathrm{nM}$, but trungapeptin A was reported to be inactive against KB or LoVo cells at $10 \mu \mathrm{g} / \mathrm{mL}$. Some cases further indicated that the unsaturated terminal moieties may play an important role in the biological activity, as illustrated by almiramide $\mathrm{B}$ and $\mathrm{C}$ possessing strong in vitro antiparasitic activity against $L$. donovani, whereas almiramide A was completely inactive.

Another research area to exploit marine peptides as a source of new therapeutics is to harness the genetic versatility of its biosynthetic gene clusters. Acetylenases, a special family of desaturases that catalyze $\mathrm{O}_{2}$-dependent dehydrogenation of $\mathrm{C}-\mathrm{C}$ bonds, have been considered to be responsible for formation of terminal alkynes of many natural products [15]. In 2015, Zhu and Zhang et al. reported a thorough characterization of terminal alkyne biosynthetic enzymes responsible for the synthesis of jamaicamide A and B (65-66) and carmabins [51,52], which demonstrated the in vitro formation of a short-chain alkynoic starter unit by a three-gene operon, jam $A B C$, where jam $A$, jam $B$ and jam $C$ encode a homolog of fatty acyl-CoA ligase, a membrane-bound fatty acid desaturase and an acyl carrier protein $(\mathrm{ACP})$, respectively [53]. Therefore, the biosynthetic evidences have further shown that the fatty acyl starter unit and the extender units could be engineered using jam $A B C$ and other modular assembly lines of PKS/NRPS enzymatic machinery to form the terminal alkyne-containing natural product.

A well-known reaction referred to as the "click reaction" (the triazole forming via azide-alkyne cyclo addition), has been quite often used in selective imaging and study of azide- or alkyne-labeled macromolecule interaction. In our opinion, the azide-alkyne click chemistry may serve as a powerful tool to study the drug mechanism of the terminal alkyne-containing peptides as well as to explore their structure activity relationship (SAR). Not surprisingly, it is highly expected to see application of the "click reaction" in combination with the biosynthetically engineered alkynyl-containing peptides playing a role in drug discovery research in the near future.

Acknowledgments: The authors acknowledge the National Natural Science Fund of China (No. 41476121, 81402844, 81302691, 81373321, 41106127, 81172978, 81072573, and 81001394).

Author Contributions: Bing-Nan Han and Qiu-Ye Chai were responsible for writing the review. Zhen Yang assisted in providing references and the final editing the manuscript. Hou-Wen Lin and Bing-Nan Han were in charge of the financial support of this project.

Conflicts of Interest: The authors declare no conflict of interest. 


\section{References}

1. Costa, M.; Costa-Rodrigues, J.; Fernandes, M.H.; Barros, P.; Vasconcelos, V.; Martins, R. Marine cyanobacteria compounds with anticancer properties: A review on the implication of apoptosis. Mar. Drugs 2012, 10, 2181-2207. [CrossRef] [PubMed]

2. Cheung, R.C.; Ng, T.B.; Wong, J.H. Marine peptides: Bioactivities and applications. Mar. Drugs 2015, 13, 4006-4043. [CrossRef] [PubMed]

3. Jo, C.; Khan, F.F.; Khan, M.I.; Iqbal, J. Marine bioactive peptides: Types, structures, and physiological functions. Food Rev. Int. 2016, 33, 44-61. [CrossRef]

4. Zheng, L.H.; Wang, Y.J.; Sheng, J.; Wang, F.; Zheng, Y.; Lin, X.K.; Sun, M. Antitumor peptides from marine organisms. Mar. Drugs 2011, 9, 1840-1859. [CrossRef] [PubMed]

5. Sipkema, D.; Franssen, M.C.; Osinga, R.; Tramper, J.; Wijffels, R.H. Marine sponges as pharmacy. Mar. Biotechnol. 2005, 7, 142-162. [CrossRef] [PubMed]

6. Andavan, G.S.; Lemmens-Gruber, R. Cyclodepsipeptides from marine sponges: Natural agents for drug research. Mar. Drugs 2010, 8, 810-834. [CrossRef] [PubMed]

7. Rawat, D.S.; Joshi, M.C.; Joshi, P.; Atheaya, H. Marine peptides and related compounds in clinical trial. Anti-Cancer Agents Med. Chem. 2006, 6, 33-40. [CrossRef]

8. Blunt, J.W.; Copp, B.R.; Keyzers, R.A.; Munro, M.H.; Prinsep, M.R. Marine natural products. Nat. Prod. Rep. 2014, 31, 160-258. [CrossRef] [PubMed]

9. Park, Y.J.; Jeong, J.-K.; Choi, Y.M.; Lee, M.S.; Choi, J.H.; Cho, E.J.; Song, H.; Park, S.J.; Lee, J.-H.; Hong, S.S. Dolastatin-10 derivative method of producing the same and anticancer drug composition containing the same. J. Am. Chem. Soc. 1987, 109, 6883-6885.

10. Luesch, H.; Moore, R.E.; Paul, V.J.; Mooberry, S.L.; Corbett, T.H. Isolation of dolastatin 10 from the marine cyanobacterium symploca species vp642 and total stereochemistry and biological evaluation of its analogue symplostatin 1. J. Nat. Prod. 2001, 64, 907-910. [CrossRef] [PubMed]

11. Rodríguez, J.; Fernández, R.; Quiñoá, E.; Riguera, R.; Debitus, C.; Bouchetj, P. Onchidin: A cytotoxic depsipeptide with $C_{2}$ symmetry from a marine mollusc. Tetmhedron Lett. 1994, 35, 9239-9242. [CrossRef]

12. Sitachitta, N.; Williamson, R.T.; Gerwick, W.H. Yanucamides a and b, two new depsipeptides from an assemblage of the marine cyanobacteria Lyngbya majuscula and Schizothrix species. J. Nat. Prod. 2000, 63, 197-200. [CrossRef] [PubMed]

13. Mevers, E.; Liu, W.T.; Engene, N.; Mohimani, H.; Byrum, T.; Pevzner, P.A.; Dorrestein, P.C.; Spadafora, C.; Gerwick, W.H. Cytotoxic veraguamides, alkynyl bromide-containing cyclic depsipeptides from the marine cyanobacterium cf. Oscillatoria margaritifera. J. Nat. Prod. 2011, 74, 928-936. [CrossRef] [PubMed]

14. Sanchez, L.M.; Lopez, D.; Vesely, B.A.; Della Togna, G.; Gerwick, W.H.; Kyle, D.E.; Linington, R.G. Almiramides a-c: Discovery and development of a new class of leishmaniasis lead compounds. J. Med. Chem. 2010, 53, 4187-4197. [CrossRef] [PubMed]

15. Minto, R.E.; Blacklock, B.J. Biosynthesis and function of polyacetylenes and allied natural products. Prog. Lipid Res. 2008, 47, 233-306. [CrossRef] [PubMed]

16. Yamaguchi, M.; Park, H.-J.; Ishizuka, S.; Omata, K.; Hirama, M. Chemistry and antimicrobial activity of caryoynencins analogs. J. Med. Chem. 1995, 38, 5015-5022. [CrossRef] [PubMed]

17. Nagarajan, M.; Maruthanayagam, V.; Sundararaman, M. A review of pharmacological and toxicological potentials of marine cyanobacterial metabolites. J. Appl. Toxicol. 2012, 32, 153-185. [CrossRef] [PubMed]

18. Raja, R.; Hemaiswarya, S.; Ganesan, V.; Carvalho, I.S. Recent developments in therapeutic applications of cyanobacteria. Crit. Rev. Microbiol. 2016, 42, 394-405. [CrossRef] [PubMed]

19. Chapman, A.D. Numbers of Living Species in Australia and the World; Departmwnt of the Environment: Canberra, Australia, 2010.

20. Aneiros, A.; Garateix, A. Bioactive peptides from marine sources: Pharmacological properties and isolation procedures. J. Chromatogr. B Anal. Technol. Biomed. Life Sci. 2004, 803, 41-53. [CrossRef] [PubMed]

21. Suarez-Jimenez, G.M.; Burgos-Hernandez, A.; Ezquerra-Brauer, J.M. Bioactive peptides and depsipeptides with anticancer potential: Sources from marine animals. Mar. Drugs 2012, 10, 963-986. [CrossRef] [PubMed]

22. Luesch, H.; Pangilinan, R.; Yoshida, W.Y.; Moore, R.E.; Paul, V.J. Pitipeptolides a and b, new cyclodepsipeptides from the marine cyanobacterium Lyngbya majuscula. J. Nat. Prod. 2001, 64, 304-307. [CrossRef] [PubMed] 
23. Han, B.; Gross, H.; McPhail, K.L.; Goeger, D.; Maier, C.S.; Gerwick, W.H. Wewakamide a and guineamide $\mathrm{g}$, cyclic depsipeptides from the marine cyanobacteria Lyngbya semiplena and Lyngbya majuscula. J. Microbiol. Biotechnol. 2011, 21, 930-936. [CrossRef] [PubMed]

24. Wan, F.; Erickson, K.L. Georgamide, a new cyclic depsipeptide with an alkynoic acid residue from an australian cyanobacterium. J. Nat. Prod. 2001, 64, 143-146. [CrossRef] [PubMed]

25. Liu, W.-T.; Ng, J.; Meluzzi, D.; Bandeira, N.; Gutierrez, M.; Simmons, T.L.; Schultz, A.W.; Linington, R.G.; Moore, B.S.; Gerwick, W.H.; et al. Interpretation of tandem mass spectra obtained from cyclic nonribosomal peptides. Anal. Chem. 2009, 81, 4200-4209. [CrossRef] [PubMed]

26. Montaser, R.; Paul, V.J.; Luesch, H. Pitipeptolides c-f, antimycobacterial cyclodepsipeptides from the marine cyanobacterium Lyngbya majuscula from guam. Phytochemistry 2011, 72, 2068-2074. [CrossRef] [PubMed]

27. Gunasekera, S.P.; Owle, C.S.; Montaser, R.; Luesch, H.; Paul, V.J. Malyngamide 3 and cocosamides a and b from the marine cyanobacterium Lyngbya majuscula from cocos lagoon, guam. J. Nat. Prod. 2011, 74, 871-876. [CrossRef] [PubMed]

28. Boudreau, P.D.; Byrum, T.; Liu, W.T.; Dorrestein, P.C.; Gerwick, W.H. Viequeamide a, a cytotoxic member of the kulolide superfamily of cyclic depsipeptides from a marine button cyanobacterium. J. Nat. Prod. 2012, 75, 1560-1570. [CrossRef] [PubMed]

29. Reese, M.T.; Gulavita, N.K.; Nakao, Y.; Hamann, M.T.; Yoshida, W.Y.; Coval, S.J.; Scheuer, P.J. Kulolide: A cytotoxic depsipeptide from a cephalaspidean mollusk, philinopsis speciosa1. J. Am. Chem. Soc. 1996, 118, 11081-11084. [CrossRef]

30. Nakao, Y.; Yoshida, W.Y.; Szabo, C.M.; Baker, B.J.; Scheuer, P.J. More peptides and other diverse constituents of the marine mollusk philinopsis speciosa. J. Org. Chem. 1998, 63, 3272-3280. [CrossRef]

31. Han, B.; Goeger, D.; Maier, C.S.; Gerwick, W.H. The wewakpeptins, cyclic depsipeptides from a papua new guinea collection of the marine cyanobacterium Lyngbya semiplena. J. Org. Chem. 2004, 70, 3133-3139. [CrossRef] [PubMed]

32. Horgen, F.D.; Yoshida, W.Y; Scheuer, P.J. Malevamides a-c, new depsipeptides from the marine cyanobacterium symploca laete-viridis. J. Nat. Prod. 2000, 63, 461-467. [CrossRef] [PubMed]

33. Tan, L.T.; Sitachitta, N.; Gerwick, W.H. The guineamides, novel cyclic depsipeptides from a papua new guinea collection of the marine cyanobacterium Lyngbya majuscula. J. Nat. Prod. 2002, 66, 764-771. [CrossRef] [PubMed]

34. Williams, P.G.; Yoshida, W.Y.; Quon, M.K.; Moore, R.E.; Paul, V.J. Ulongapeptin, a cytotoxic cyclic depsipeptide from a palauan marine cyanobacterium Lyngbya sp. J. Nat. Prod. 2003, 66, 651-654. [CrossRef] [PubMed]

35. Vining, O.B.; Medina, R.A.; Mitchell, E.A.; Videau, P.; Li, D.; Serrill, J.D.; Kelly, J.X.; Gerwick, W.H.; Proteau, P.J.; Ishmael, J.E.; et al. Depsipeptide companeramides from a panamanian marine cyanobacterium associated with the coibamide producer. J. Nat. Prod. 2015, 78, 413-420. [CrossRef] [PubMed]

36. Fernández, R.; Rodríguez, J.; Quiñoá, E.; Riguera, R.; Muñoz, L.; Fernández-Suárez, M.; Debitus, C. Onchidin b: A new cyclodepsipeptide from the mollusc Onchidium sp. J. Am. Chem. Soc. 1996, 118, 11635-11643. [CrossRef]

37. Nogle, L.M.; Gerwick, W.H. Isolation of four new cyclic depsipeptides, antanapeptins a-d, and dolastatin 16 from a madagascan collection of Lyngbya majuscula. J. Nat. Prod. 2001, 65, 21-24. [CrossRef]

38. Bunyajetpong, S.; Yoshida, W.Y.; Sitachitta, N.; Kaya, K. Trungapeptins A-C, cyclodepsipeptides from the marine cyanobacterium Lyngbya majuscula. J. Nat. Prod. 2006, 69, 1539-1542. [CrossRef] [PubMed]

39. Tripathi, A.; Puddic, J.; Prinsep, M.R.; Lee, P.P.F.; Tan, L.T. Hantupeptin a, a cytotoxic cyclic depsipeptide from a singapore collection of Lyngbya majuscula. J. Nat. Prod. 2009, 72, 29-32. [CrossRef] [PubMed]

40. Salvador, L.A.; Biggs, J.S.; Paul, V.J.; Luesch, H. Veraguamides a-g, cyclic hexadepsipeptides from a dolastatin 16-producing cyanobacterium symploca cf. Hydnoides from guam. J. Nat. Prod. 2011, 74, 917-927. [CrossRef] [PubMed]

41. Williams, P.G.; Yoshida, W.Y.; Quon, M.K.; Moore, R.E.; Paul, V.J. The structure of palau'amide, a potent cytotoxin from a species of the marine cyanobacterium Lyngbya. J. Nat. Prod. 2003, 66, 1545-1549. [CrossRef] [PubMed]

42. Pettit, G.R. Isolation and Stuctural Elucidation of the Cytostatic Linear and Cyclo-Depsipeptides Dolastatin 16, Dolastatin 17, and Dolastatin 18. U.S. Patent 6,239,104 B1, 29 May 2001. 
43. Luesch, H.; Yoshida, W.Y.; Moore, R.E.; Paul, V.J. Apramides a-g, novel lipopeptides from the marine cyanobacterium Lyngbya majuscula. J. Nat. Prod. 2000, 63, 1106-1112. [CrossRef] [PubMed]

44. Jiménez, J.I.; Scheuer, P.J. New lipopeptides from the caribbean cyanobacterium Lyngbya majuscula. J. Nat. Prod. 2001, 64, 200-203. [CrossRef] [PubMed]

45. McPhail, K.L.; Correa, J.; Linington, R.G.; González, J.; Ortega-Barría, E.; Capson, T.L.; Gerwick, W.H. Antimalarial linear lipopeptides from a panamanian strain of the marine cyanobacterium Lyngbya majuscula. J. Nat. Prod. 2007, 70, 984-988. [CrossRef] [PubMed]

46. Balunas, M.J.; Linington, R.G.; Tidgewell, K.; Fenner, A.M.; Ureña, L.-D.; Togna, G.D.; Kyle, D.E.; Gerwick, W.H. Dragonamide e, a modified linear lipopeptide from Lyngbya majuscula with antileishmanial activity. J. Nat. Prod. 2010, 73, 60-66. [CrossRef] [PubMed]

47. Gunasekera, S.P.; Ross, C.; Paul, V.J.; Matthew, S.; Luesch, H. Dragonamides c and d, linear lipopeptides from the marine cyanobacterium brown Lyngbya polychroa. J. Nat. Prod. 2008, 71, 887-890. [CrossRef] [PubMed]

48. Quintana, J.; Bayona, L.M.; Castellanos, L.; Puyana, M.; Camargo, P.; Aristizabal, F.; Edwards, C.; Tabudravu, J.N.; Jaspars, M.; Ramos, F.A. Almiramide d, cytotoxic peptide from the marine cyanobacterium oscillatoria nigroviridis. Bioorg. Med. Chem. 2014, 22, 6789-6795. [CrossRef] [PubMed]

49. Simmons, T.L.; Engene, N.; Ureña, L.D.; Romero, L.I.; Ortega-Barría, E.; Gerwick, L.; Gerwick, W.H. Viridamides $a$ and $b$, lipodepsipeptides with antiprotozoal activity from the marine cyanobacterium oscillatoria nigro-wiridis. J. Nat. Prod. 2008, 71, 1544-1550. [CrossRef] [PubMed]

50. Hooper, G.J.; Orjala, J.; Schatzman, R.C.; Gerwick, W.H. Carmabins a and b, new lipopeptides from the caribbean cyanobacterium Lyngbya majuscula. J. Nat. Prod. 1998, 61, 529-533. [CrossRef] [PubMed]

51. Edwards, D.J.; Marquez, B.L.; Nogle, L.M.; McPhail, K.; Goeger, D.E.; Roberts, M.A.; Gerwick, W.H. Structure and biosynthesis of the jamaicamides, new mixed polyketide-peptide neurotoxins from the marine cyanobacterium Lyngbya majuscula. Chem. Biol. 2004, 11, 817-833. [CrossRef] [PubMed]

52. Jones, A.C.; Monroe, E.A.; Podell, S.; Hess, W.R.; Klages, S.; Esquenazi, E.; Niessen, S.; Hoover, H.; Rothmann, M.; Lasken, R.S.; et al. Genomic insights into the physiology and ecology of the marine filamentous cyanobacterium Lyngbya majuscula. Proc. Natl. Acad. Sci. USA 2011, 108, 8815-8820. [CrossRef] [PubMed]

53. Zhu, X.; Liu, J.; Zhang, W. De novo biosynthesis of terminal alkyne-labeled natural products. Nat. Chem. Boil. 2015, 11, 115-120. [CrossRef] [PubMed]

54. Cruz-Rivera, E.; Paul, V.J. Chemical deterrence of a cyanobacterial metabolite against generalized and specialized grazers. J. Chem. Ecol. 2007, 33, 213-217. [CrossRef] [PubMed]

55. Xu, Z.; Peng, Y.; Ye, T. The total synthesis and stereochemical revision of yanucamide a. Org. Lett. 2003, 5, 2821-2824. [CrossRef] [PubMed]

56. Vorde, C.; Hogberg, H.-E.; Hedenström, E. Resolution of 2-methylalkanoic esters: Enantioselective aminolysis by $(R)-1$-phenylethylamine of ethyl 2-methyloctanoate catalysed by lipase B from Candida antarctica. Tetrahedron Asymmetry 1996, 7, 1507-1513. [CrossRef]

57. Engel, K.-H. Lipase-catalyzed enantioselective esterification of 2-methylalkanoic acids. Tetrahedron Asymmetry 1991, 2, 165-168. [CrossRef]

58. Berglund, P.; Holmquist, M.; Hedenstrom, E.; Hult, K.; Hiigberg, H.-E. 2-Methylalkanoic acids resolved by esterification catalysed by lipase from candida rugosa: Alcohol chain length and enantioselectivity. Tetrahedron Asymmetry 1993, 4, 1869-1878. [CrossRef]

(C) 2016 by the authors; licensee MDPI, Basel, Switzerland. This article is an open access article distributed under the terms and conditions of the Creative Commons Attribution (CC-BY) license (http://creativecommons.org/licenses/by/4.0/). 